Bangladesh J. Sci. Res. 26(1\&2): 57-60, 2013 (December)

\title{
INFLUENCE OF SEWAGE SLUDGE ON YIELD AND MINERAL CONTENTS OF RICE GRAIN
}

\author{
A.T.M.M. Kamal", M.M. Islam, M.S. Hossain and S.M. Ullah \\ Department of Soil, Water and Environment, University of Dhaka, Dhaka-1000, Bangladesh
}

\begin{abstract}
Sewage sludge at the rate of 0,40, 80, 120 and 240 t/ha showed that the number of filled grains per panicle, dry weight of grains and weight of 1000 grains of rice (Oryza sativa L.) were the significantly highest where 240 tons of sewage sludge per hectare was added. The contents of $\mathrm{N}, \mathrm{P}, \mathrm{K}, \mathrm{Ca}, \mathrm{Mg}, \mathrm{Fe}, \mathrm{Cu}, \mathrm{Zn}$ and $\mathrm{Pb}$ in rice grains increased significantly with increasing rate of sewage sludge application, while that of $\mathrm{Mn}$ decreased significantly. Chromium, cadmium and nickel contents in the rice grain were below detection limit.
\end{abstract}

Key words: Sewage sludge, rice grain yield, mineral contents

\section{Introduction}

Sewage sludge is an organic residue containing large amounts of mineral elements (N, P, K, Ca and $\mathrm{Mg}$ ) and microelements ( $\mathrm{Zn}, \mathrm{Cu}, \mathrm{Mn}$ and $\mathrm{B}$ ), that influence plant growth and yield (Parat et al. 2005, Mohammad and Athamneh 2004 and Henze et al. 2002). It has been widely used in cropped land especially in Europe, America and some parts of Asia. Its application to soils not only improves organic matter and essential nutrient contents, but also improves soil physical and microbial conditions (Parat et al. 2005, Mohammad and Athamneh 2004 and Webber et al. 1996). However, it may cause a potential hazard, especially heavy metal pollution (Cd, $\mathrm{Ni}, \mathrm{Cu}, \mathrm{Zn}$ and other metals) to soil (Bozkurt and Yarilgac 2003, Mohammad and Athamneh 2004).

Approximately 54,750 tons of sewage sludge containing about 1,000 to 1,400 tons of nitrogen and 350 to 500 tons of phosphorus are produced per year in Dhaka city (BARC 1997). However, information regarding the potential use of sewage sludge on agricultural land and its consequences on soils as well as crops is scarce. Therefore, the objective of this study is to find out the effect of sewage sludge on yield and mineral contents of rice grain.

\section{Materials and Methods}

The experimental soil (0 - $15 \mathrm{~cm}$ depth) was collected from low lying area of Zirani, Savar, Dhaka. Dried sewage sludge (SS) was collected from Dhaka WASA sewage treatment plant, Pagla, Narayanganj. The collected soil and sewage sludge samples were air-dried, ground and sieved through a $2 \mathrm{~mm}$ sieve for physical analysis. Total N, P, Na, K, Ca, Mg, Fe, Cu, Zn, Mn, Pb, and $\mathrm{Cr}$ contents of sewage sludge were 1.705, 0.98, 0.022, 0.092, 0.069, 0.043, 1.17, 0.025, 0.21, $0.028 \%, 186$ and $29 \mu \mathrm{g} / \mathrm{g}$, respectively. The total contents of $\mathrm{Cd}$ and $\mathrm{Ni}$ in sewage sludge were below detection limit.

*Corresponding author: <atmkamal@du.ac.bd>. 
A pot experiment was laid out in a completely randomized design with five treatments of sewage sludge $(0,40,80,120$ and $240 \mathrm{t}$ /ha) with BRRI dhan 29 grown in boro season with three replications. Sewage sludge was added to each pot containing $8 \mathrm{~kg}$ soil, 14 days before transplantion. Basal doses of $\mathrm{N}$ (25 kg/ha), $\mathrm{P}\left(80 \mathrm{~kg} \mathrm{P}_{2} \mathrm{O}_{5} / \mathrm{ha}\right)$ and $\mathrm{K}(80 \mathrm{~kg} \mathrm{~K} \mathrm{O} / \mathrm{ha})$ were applied. One hundred $\mathrm{kg} \mathrm{N} / \mathrm{ha}$ was applied to $\mathrm{SS}_{0}$ treatment to achieve the normal growth of rice. Fifty per cent of $\mathrm{N}$ was applied at the time of pot preparation and the rest $50 \% \mathrm{~N}$ was top dressed in two equal splits after 55 and 100 days of transplantation. Eight uniform rice seedlings of seven weeks old were transplanted ( 2 seedlings/hill) in each pot but after 15 days, only the best four were allowed to grow. Pots were irrigated properly with normal tap water and intercultural operations were done whenever necessary. At maturity dry weight of rice grain, weight of 1000 grains and the number of filled and non-filled grains were determined.

Total N content of rice grain was determined by Micro-Kjeldhal's method (Jackson 1973). The total contents of $\mathrm{Ca}, \mathrm{Mg}, \mathrm{Fe}, \mathrm{Zn}, \mathrm{Cu}, \mathrm{Mn}, \mathrm{Pb}, \mathrm{Cr}, \mathrm{Cd}$ and $\mathrm{Ni}$ were determined after wet digestion of rice grain by $\mathrm{HNO}_{3}-\mathrm{HClO}_{4}$ acid mixture $(5: 1)$ using atomic absorption spectrometer (Perkin Elmer 3110). The total P and K contents were determined colorimetrically and flame photomertically, repectively. The results were statistically analyzed (Gomez and Gomez 1976).

\section{Results and Discussion}

Results showed that the number of filled grains per panicle, dry weight of grains and weight of 1000 grains were found highest in the treatment $\mathrm{SS}_{240}$, while decreased significantly with decreasing sewage sludge applications, but no significant difference was found in most of the treatments (Table 1). Significantly the lowest number of non-filled grains per panicle was observed in the treatment $\mathrm{SS}_{0}$ and the highest in the treatment $\mathrm{SS}_{40}$. The yield contributing

Table 1. Effects of different levels of sewage sludge on the selected parameters of rice grain.

\begin{tabular}{llccc}
\hline \multirow{2}{*}{$\begin{array}{c}\text { Treatments } \\
(\mathrm{kg} / \mathrm{ha})\end{array}$} & \multicolumn{2}{l}{ Number of grains/panicle } & $\begin{array}{c}\text { Dry weight of } \\
\text { grains (g/pot) }\end{array}$ & $\begin{array}{c}\text { Weight of } 1000 \\
\text { grains (g) }\end{array}$ \\
\cline { 2 - 3 } $\mathrm{SS}_{0}$ & $72.91^{\mathrm{a}}$ & $35.29^{\mathrm{d}}$ & $42.11^{\mathrm{a}}$ & $29.14^{\mathrm{a}}$ \\
$\mathrm{SS}_{40}$ & $57.52^{\mathrm{c}}$ & $40.26^{\mathrm{a}}$ & $35.18^{\mathrm{c}}$ & $22.83^{\mathrm{d}}$ \\
$\mathrm{SS}_{80}$ & $63.35^{\mathrm{b}}$ & $38.92^{\mathrm{b}}$ & $36.39^{\mathrm{bc}}$ & $24.35^{\mathrm{c}}$ \\
$\mathrm{SS}_{120}$ & $67.17^{\mathrm{b}}$ & $36.78^{\mathrm{c}}$ & $37.40^{\mathrm{b}}$ & $26.13^{\mathrm{b}}$ \\
$\mathrm{SS}_{240}$ & $73.14^{\mathrm{a}}$ & $36.50^{\mathrm{cd}}$ & $43.30^{\mathrm{a}}$ & $30.00^{\mathrm{a}}$ \\
\hline
\end{tabular}

Means followed by the same letter(s) in a column do not differ significantly from each other at $5 \%$ level of DMRT.

characteristics were the highest in the treatment $\mathrm{SS}_{240}$. This might be due to the fulfilment of nutrient requirements provided by the treatment $\mathrm{SS}_{240}$. Increased yields of maize (Costica et al. 2007), sunflower (Lavado 2006) and rice grain (Kabir et al. 2011) were reported from sewage sludge application. 
The contents of $\mathrm{N}, \mathrm{P}, \mathrm{K}, \mathrm{Ca}$ and $\mathrm{Mg}$ in the rice grain increased gradually with increasing sewage sludge application and were significantly highest in $\mathrm{SS}_{240}$ treatment (Table 2). However, in the case of N, P, K, Ca and Mg no significant difference was observed in most of the treatments as in the case of growth parameters. The elevated $\mathrm{N}$ and $\mathrm{P}$ contents in rice grain might be due to the better supply of $\mathrm{N}$ and $\mathrm{P}$ through mineralization of added sewage sludge (Costica et al. 2007). The higher contents of nitrogen in silage maize and oat (Avena sativa L.) from soil amended with sewage sludge were observed by Cerny et al. (2012) and Peterson et al. (2003), respectively. Rice grains accumulated more $\mathrm{K}, \mathrm{Ca}$ and $\mathrm{Mg}$ probably due to its availability from applied sewage sludge (Hinesly et al. 1979).

Table 2. Effects of different levels of sewage sludge on the mineral contents of rice grain.

\begin{tabular}{|c|c|c|c|c|c|}
\hline \multirow{3}{*}{$\begin{array}{l}\text { Treatments } \\
\text { (kg/ha) }\end{array}$} & \multicolumn{5}{|c|}{ Mineral content } \\
\hline & \multirow{2}{*}{$\begin{array}{l}\% \\
\mathrm{~N} \\
\end{array}$} & \multicolumn{4}{|c|}{$(\mu \mathrm{g} / \mathrm{g})$} \\
\hline & & $\mathrm{P}$ & $\mathrm{K}$ & $\mathrm{Ca}$ & $\mathrm{Mg}$ \\
\hline $\mathrm{SS}_{0}$ & $0.83^{d}$ & $164^{\mathrm{c}}$ & $460^{c}$ & $420^{c}$ & $230^{d}$ \\
\hline $\mathrm{SS}_{40}$ & $1.05^{\mathrm{c}}$ & $172^{\mathrm{c}}$ & $520^{c}$ & $510^{b}$ & $380^{c}$ \\
\hline $\mathrm{SS}_{80}$ & $1.17^{\mathrm{b}}$ & $190^{\mathrm{bc}}$ & $770^{\mathrm{b}}$ & $550^{\mathrm{b}}$ & $420^{\mathrm{bc}}$ \\
\hline $\mathrm{SS}_{120}$ & $1.21^{\mathrm{b}}$ & $211^{b}$ & $870^{\mathrm{b}}$ & $560^{\mathrm{b}}$ & $470^{\mathrm{ab}}$ \\
\hline $\mathrm{SS}_{240}$ & $1.91^{\mathrm{a}}$ & $254^{\mathrm{a}}$ & $1020^{\mathrm{a}}$ & $660^{\mathrm{a}}$ & $490^{a}$ \\
\hline
\end{tabular}

Means followed by the same letter(s) in a column do not differ significantly from each other at $5 \%$ level of DMRT.

Significantly the lowest and highest amounts of heavy metals such as $\mathrm{Fe}, \mathrm{Cu}, \mathrm{Zn}$ and $\mathrm{Pb}$ were observed in $\mathrm{SS}_{0}$ and $\mathrm{SS}_{120}$ treatments, respectively (Table 3). The contents of $\mathrm{Fe}, \mathrm{Cu}, \mathrm{Zn}$ and $\mathrm{Pb}$ in the rice grain increased significantly with the increasing rate of sewage sludge application. $\mathrm{Fe}, \mathrm{Cu}$ and $\mathrm{Zn}$ concentrations in maize grain were reported high in Zimbabwe due to heavy fertilization with sewage sludge (Muchuweti et al. 2006). In wheat grain, the content of $\mathrm{Fe}, \mathrm{Cu}, \mathrm{Zn}$ and $\mathrm{P}$

Table 3. Effects of different levels of sewage sludge on the heavy metal content $(\mu \mathrm{g} / \mathrm{g})$ of rice grain.

\begin{tabular}{cccccc}
\hline \multirow{2}{*}{$\begin{array}{c}\text { Treatment } \\
(\mathrm{kg} / \mathrm{ha})\end{array}$} & \multicolumn{5}{c}{ Heavy metal content $(\mu \mathrm{g} / \mathrm{g})$} \\
\cline { 2 - 6 } & $\mathrm{Fe}$ & $\mathrm{Cu}$ & $\mathrm{Zn}$ & $\mathrm{Mn}$ & $\mathrm{Pb}$ \\
\hline $\mathrm{SS}_{0}$ & $482.33^{\mathrm{e}}$ & $27.75^{\mathrm{e}}$ & $74.68^{\mathrm{e}}$ & $76.61^{\mathrm{a}}$ & $10.02^{\mathrm{e}}$ \\
$\mathrm{SS}_{40}$ & $508.67^{\mathrm{d}}$ & $32.84^{\mathrm{d}}$ & $88.35^{\mathrm{d}}$ & $66.25^{\mathrm{b}}$ & $21.01^{\mathrm{d}}$ \\
$\mathrm{SS}_{80}$ & $522.34^{\mathrm{c}}$ & $49.56^{\mathrm{c}}$ & $96.19^{\mathrm{c}}$ & $49.73^{\mathrm{c}}$ & $27.26^{\mathrm{c}}$ \\
$\mathrm{SS}_{120}$ & $643.00^{\mathrm{b}}$ & $52.02^{\mathrm{b}}$ & $98.97^{\mathrm{b}}$ & $43.47^{\mathrm{d}}$ & $33.69^{\mathrm{b}}$ \\
$\mathrm{SS}_{240}$ & $719.00^{\mathrm{a}}$ & $55.32^{\mathrm{a}}$ & $102.23^{\mathrm{a}}$ & $33.34^{\mathrm{e}}$ & $47.32^{\mathrm{a}}$ \\
\hline
\end{tabular}

Means followed by the same letter(s) in a column do not differ significantly from each other at $5 \%$ level of DMRT.

increased with the increase in sewage sludge application (Hinesly et al. 1979). Manganese content in the rice grain decreased significantly with increasing rate of sewage sludge application. This 
could be due to the less availability of Mn by the added sewage sludge (Hinesly et al. 1979, Hiroki and Fujii 1984). No detectable contents of $\mathrm{Cr}$, $\mathrm{Cd}$ and $\mathrm{Ni}$ were found in the rice grain.

\section{References}

BARC. 1997. Fertilizer recommendation guide, Soil and irrigation publication No. 13, Bangladesh Agricultural Research Council (BARC), BARC publishing section, Farm gate, Dhaka, Bangladesh.

Bozkurt, M.A. and T. Yarilgac, 2003. The effects of sewage sludge applications on the yield, growth, nutrition and heavy metal accumulation in apple trees growing in dry conditions. Turk J. Agric. For. 27: 285-292.

Cerny, J., J. Balík, M. Kulhanek, F. Vasak, L. Peklova, and O. Sedlar. 2012. The effect of mineral N fertilizer and sewage sludge on yield and nitrogen efficiency of silage maize. Plant Soil Environ. 58: 76-83.

Costica, A., J. Gerard, B. Daniel, and A. Despina. 2007. Influence of sewage sludge on maize yield and quality and soil chemical characteristics. J. Food, Agric. Environ. 5: 310-313.

Gomez, K. A. and A. A. Gomez. 1976. Statistical procedures for agricultural research with emphasis on rice. The International Rice Research Institute, Philippines, pp. 10-53.

Henze, M., P. Harremoes, J.I. Cour Jansen and Arvin, E. 2002. Wastewater treatment. Springer, Berlin.

Hinsey, T.D., V. Dudarski-Hack, D.E. Alexander, E.L. Zinegler and G.L. Barrett. 1979. The American Cssociation of Cereal Chemists. 56:283-287.

Hiroki, M. and K. Fujii. 1984. Growth and element content of rice cultivated on paddy soil with application of sewage sludge. Research report, National Institute of Environmental Studies, No. 68.17-29.

Jackson, M.L. 1973. Soil Chemical Analysis. Prentice Hall Inc. New Jersy, USA.

Kabir, M.K., A.T.M.M. Kamal, S. Jahan, A.M.M. Faizullah and S.M. Ullah, 2011, Yield of rice and its mineral contents as influenced by sewage sludge and nitrogen, Bangladesh. J. Sci. Res. 24: 161-168.

Lavado, S. Raül. 2006. Effects of sewage sludge application on soils and sunflower yield : Quality and toxic element accumulation. J. Plant Nutrition 29:975-984.

Mohammad, M.J. and B.M. Athamneh, 2004. Changes in soil fertility and plant uptake of nutrients nd heavy metals in response to sewage sludge application to calcareous soils. J. Agron. 3: 229-236.

Muchuweti, M., J.W. Birkett, E. Chinyanga, R. Zvauya, M.D. Scrimshaw and J.N. Lester. 2006. Heavy metal content of vegetables irrigated with mixtures of wastewater and sewage sludge in Zimbabwe: Implications for human health. Agriculture, Ecos. \& Environ. 112:41-48.

Parat, C., R. Chaussod, Leveque and F. Andreux. 2005. Long-term effects of metal containing farmyard manure and sewage sludge on soil organic matter in a fluvisol. Soil Biol Biochem. 37:673-679.

Petersen, O. S., J. Peterson and G.H. Rubæk. 2003. Dynamics and plant uptake of nitrogen and phosphorus in soil amended with sewage sludge. Applied Soil Ecology 24:187-195.

Webber, M.D., H.R. Rogers, C.D. Watts, A.B.A. Boxall, R.D. Davis, and R. Scoffin. 1996. Monitoring and prioritization of organic contaminants in sewage sludge using specific chemical analysis and predictive non-analytical methods. Sci. Total Environ. 185: 27-44. 